\title{
Addition of 2-[(trimethylsilyloxy)]furan to 2-acetyl-1,4- benzoquinone using chiral non-racemic copper(II)-pybox catalysts
}

\author{
Maria D. K. N. Towers, Paul D. Woodgate and Margaret A. Brimble* \\ Department of Chemistry, The University of Auckland, Private Bag 92019, \\ Auckland, New Zealand \\ E-mail:m.brimble@auckland.ac.nz
}

(received 05 Feb 03; accepted 07 Apr 03; published on the web 29 Apr 03)

\begin{abstract}
The Michael addition of 2-[(trimethylsilyloxy)]furan 1 to 2-acetyl-1,4-benzoquinone 2 was carried out using several $\mathrm{Cu}(\mathrm{II})$-pybox catalysts. The furobenzofuran adduct $\mathbf{3}$ was prepared in good chemical yield but in low enantiomeric excess. The adduct $\mathbf{3}$ was converted into the menthyl carbonate derivative to allow determination of the enantiomeric excess by high field NMR spectroscopy.
\end{abstract}

Keywords: 2-[(Trimethylsilyloxy)]furan, quinone, annulation, pybox ligands, pyranonaphtho quinones

\section{Introduction}

We have reported previously the uncatalyzed addition of 2-[(trimethylsilyloxy]furan to 1,4benzoquinones and 1,4-naphthoquinones that bear an electron withdrawing group at C-2, as an efficient entry into the furobenzofuran and furonaphthofuran annulation products, respectively. ${ }^{1}$ The furonaphthofuran adducts then underwent smooth oxidative rearrangement to provide the pyranonaphthoquinone skeleton present in the isochromanquinone family of antibiotics (Scheme 1). ${ }^{2}$ As part of an on-going programme directed towards designing an asymmetric variant of this annulation sequence we have also investigated ${ }^{3}$ the use of bis(oxazoline)-copper(II) complexes as enantiopure catalysts for the conjugate addition of 2-[(trimethylsilyloxy)]furan $\mathbf{1}$ to 2-acetyl1,4-naphthoquinone. The aim was to prepare a chiral non-racemic furonaphthofuran intermediate, leading ultimately to enantioselective syntheses of several pyranonaphthoquinone antibiotics. This initial study proved disappointing in that only low enantioselection was observed, despite good literature precedent for high asymmetric induction using bidentate bis(oxazoline) (box) - copper(II) complexes in catalytic asymmetric Michael and Diels-Alder additions to substrates that can participate in catalyst chelation. ${ }^{4}$ 
<smiles>COc1ccco1</smiles>

\section{Scheme 1}

Several recent papers ${ }^{5,6}$ have reported superior results using tridentate pyridine bis(oxazoline) (pybox) catalysts rather than bidentate phenyl bis(oxazoline) (box) catalysts for enantioselective Mukaiyama aldol reactions using silyl enol ethers. Moreover, copper(II)-pybox complexes have been shown to be efficient chiral catalysts for the enantioselective Mukaiyama-Michael reaction

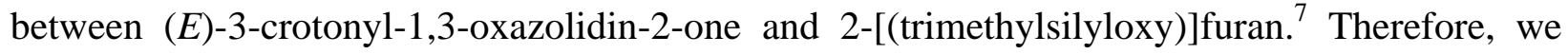
decided to evaluate the use of these pybox-metal complexes as catalysts for the enantioselective addition of 2-[(trimethylsilyloxy)]furan 1 to 2-acetyl-1,4-benzoquinone 2 (Table 1).

\section{Discussion}

Copper(II) complexes of four pybox ligands [(S,S)-(benzyl)-pybox] 4a, [(S,S)-(iso-propyl)pybox] 4b, [(S,S)-(sec-butyl)-pybox] 4c, and [(R,R)-(phenyl)-pybox] 4d were synthesised and evaluated for their ability to catalyze the addition of 2-[(trimethylsilyloxy)]furan 1 to 2-acetyl1,4-benzoquinone 2. The pybox ligands were readily prepared by condensation of 2,6pyridinedicarbonyl dichloride with either $(S)$-phenylalaninol 5a, (S)-valinol 5b, (S)-isoleucinol 5c or $(R)$-phenylglycinol 5d (Scheme 2). In turn, these latter amino alcohols were available from reduction of the appropriate amino acid with lithium borohydride-chlorotrimethylsilane. ${ }^{8}$

Two methods have been reported ${ }^{9,10}$ for the synthesis of pybox ligands. In our hands, we found that a combination of these two approaches allowed a successful synthesis of the desired ligands 4a-d. The appropriate amino alcohol $\mathbf{5}$ dissolved in isopropyl acetate was added to a solution of $1.5 \mathrm{~mol} \mathrm{~L}^{-1}$ aqueous potassium hydrogencarbonate. A solution of pyridine-2,6dicarbonyl dichloride in chloroform was added and the mixture was heated at reflux for $2.5 \mathrm{~h}$, affording the bisamide $\mathbf{6}$ in high yield. The open pybox bisamide $\mathbf{6}$ was then dissolved in chloroform and treated with thionyl chloride to promote ring closure to the pybox ligand $\mathbf{4}$, initially as its bis(hydrochloride) salt. This salt was surprisingly resistant towards neutralization, requiring treatment with $3 \mathrm{~mol} \mathrm{~L}^{-1}$ aqueous sodium hydroxide in methanol for 3 days to liberate the pybox ligand $\mathbf{4}$ as the free base. 
<smiles>[R]C([R2])(CO)NC(=O)c1cccc(C(=O)NC([R2])([R2])CO)n1</smiles>

a $\mathrm{R}^{1}=\mathrm{H}, \mathrm{R}^{2}=\mathrm{CH}_{2} \mathrm{Ph}$

b $\mathrm{R}^{1}=\mathrm{H}, \mathrm{R}^{2}={ }^{i} \mathrm{Pr}$

c $\mathrm{R}^{1}=\mathrm{H}, \mathrm{R}^{2}={ }^{\mathrm{S}} \mathrm{Bu}$

d $\mathrm{R}^{1}=\mathrm{Ph}, \mathrm{R}^{2}=\mathrm{H}$
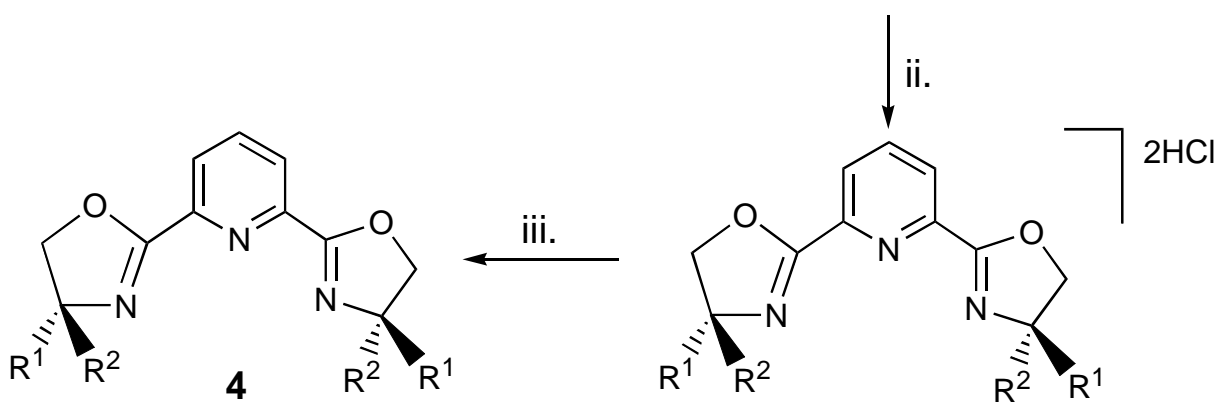

Reagents and Conditions: i. ' $\mathrm{PrOAc}, 1.5 \mathrm{~mol} \mathrm{~L}-1 \mathrm{KHCO}_{3}$; ii. $\mathrm{SOCl}_{2}$, heat, $\mathrm{CHCl}_{3}$; iii. $3 \mathrm{~mol} \mathrm{~L}{ }^{-1} \mathrm{NaOH}, \mathrm{MeOH}$, room temp., 3 days.

\section{Scheme 2}

Given that higher levels of asymmetric induction were observed ${ }^{11}$ in Diels-Alder reactions catalyzed by box-copper(II) complexes when the non-coordinating hexafluoroantimonate counterion was used, both pybox-copper(II) triflate and hexafluoroantimonate complexes were evaluated in the present study. The chiral pybox-copper(II) triflate complexes were formed by reacting pybox ligands 4a-d with copper(II) triflate in dichloromethane at room temperature for $4 \mathrm{~h}$ in the presence of $4 \AA$ molecular sieves, giving characteristically blue solutions (Scheme 3 ). The cationic hexafluoroantimonate complexes were prepared by anion exchange from the preformed copper(II) chloride complex using silver(I) hexafluoroantimonate, followed by filtration through Celite to remove the precipitated silver(I) chloride (Scheme 3).

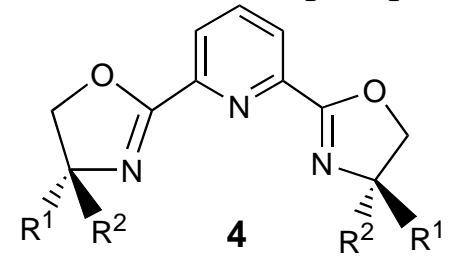

a $\mathrm{R}^{1}=\mathrm{H}, \mathrm{R}^{2}=\mathrm{CH}_{2} \mathrm{Ph} ; \boldsymbol{b} \quad \mathrm{R}^{1}=\mathrm{H}, \mathrm{R}^{2}={ }^{i} \mathrm{Pr}$

c $\mathrm{R}^{1}=\mathrm{H}, \mathrm{R}^{2}={ }^{\mathrm{s}} \mathrm{Bu}$; d $\mathrm{R}^{1}=\mathrm{Ph}, \mathrm{R}^{2}=\mathrm{H}$

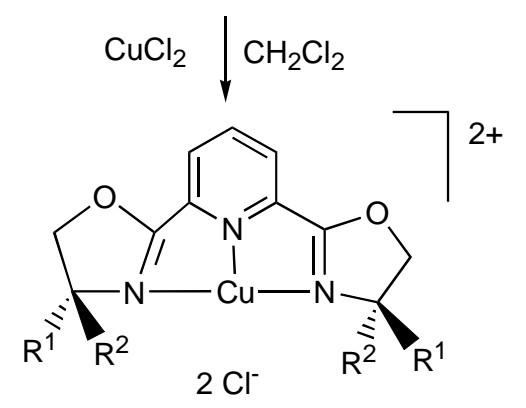

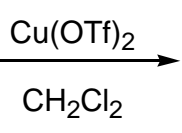

$2 \mathrm{AgSbF}_{6}$
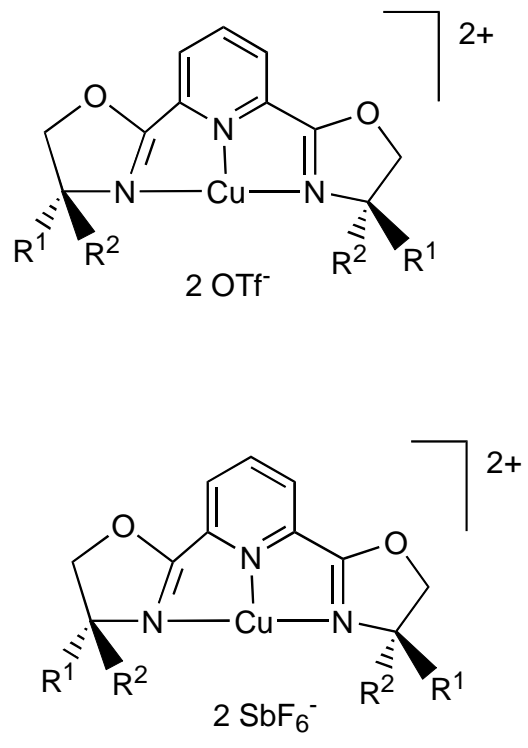


\section{Scheme 3}

Initial work (Table 1) focussed on the use of the catalyst prepared from the benzyl pybox ligand 4a and copper(II) triflate to induce asymmetry in the addition of 2-[(trimethylsilyloxy)]furan 1 to 2-acetyl-1,4-benzoquinone 2. Disappointingly, use of 5-37 mol\% catalyst afforded only the adduct 3 as a racemate. Use of a stoichiometric quantity (1 equiv.) of the copper(II) triflate complex also afforded near-racemic adduct $\mathbf{3}$, prompting investigation of hexafluoroantimonate as an alternative counterion. Although the use of this latter complex in stoichiometric amount increased the chemical yield of adduct $\mathbf{3}$, again it was racemic.

Table 1. Reaction of 2-[(trimethylsilyloxy)]furan 1 with 2-acetyl-1,4-benzoquinone 2 using pyridine bis(oxazoline)-copper complexes

\begin{tabular}{|c|c|c|c|c|}
\hline & & \\
\hline & & & \\
\hline
\end{tabular}

a \% e.e. of 3 measured by integration of the ${ }^{1} \mathrm{H}$ NMR spectrum obtained for the diastereomeric menthyl carbonate derivatives formed upon reaction with (+)-menthyl chloroformate. b Absolute configuration of major enantiomer not determined.

These results were mirrored in those obtained for the copper(II) complexes of the analogous phenyl pybox ligand $\mathbf{4 d}$; no enantioselection was observed despite using up to a stoichiometric 
quantity of either the triflate or hexafluoroantimonate complex. The only evidence for stereoselection observed in the reaction of 2-[(trimethylsilyloxy)]furan 1 with 2-acetyl-1,4benzoquinone 2 arose from the use of a stoichiometric quantity of the copper(II) triflate complex of the pybox ligand $\mathbf{4 b}$ derived from valinol, which afforded the enantiomers of adduct $\mathbf{3}$ in a ratio of 2:1. However, use of the analogous sec-butyl pybox ligand $\mathbf{4} \mathbf{c}$ under the same conditions reverted to the formation of adduct $\mathbf{3}$ as a racemate.

The enantioselectivity of the reaction was determined by conversion of the adduct $\mathbf{3}$ into its diastereoisomeric menthyl carbonate derivatives by reaction with $(+)$-menthyl chloroformate. Integration of the doublets observed at $\delta 0.81 \mathrm{ppm}$ and $\delta 0.83 \mathrm{ppm}$ for the menthyl $\mathrm{CHCH}_{3}$ groups at $\mathrm{C5}^{\prime}$ of the individual diastereoisomers allowed determination of their ratio.

It has been established that 2-[(trimethylsilyloxy)]furan $\mathbf{1}$ adds as a nucleophile in a Michael type fashion to C3 of the benzoquinone $2{ }^{12}$ There is an opportunity for asymmetric catalysis if the two adjacent carbonyl oxygens of the benzoquinone preferentially form a bidentate chelate to the Lewis acid metal centre from one face. The structure of $\{\mathrm{Cu}[(S, S)$-(isopropyl)pybox $]\}\left(\mathrm{SbF}_{6}\right)_{2}$ containing a bound substrate (via bidentate chelation) has been determined by EPR spectroscopy, and this evidence supported the hypothesis that substrates bind to this catalyst in a five-coordinate square pyramidal geometry. ${ }^{13}$ In the Michael addition pathway, it is thought that the two electronegative triflate counterions are displaced successively by the two adjacent carbonyl oxygens on the 2-acetylbenzoquinone, resulting in square pyramidal geometry of the catalyst-substrate complex.
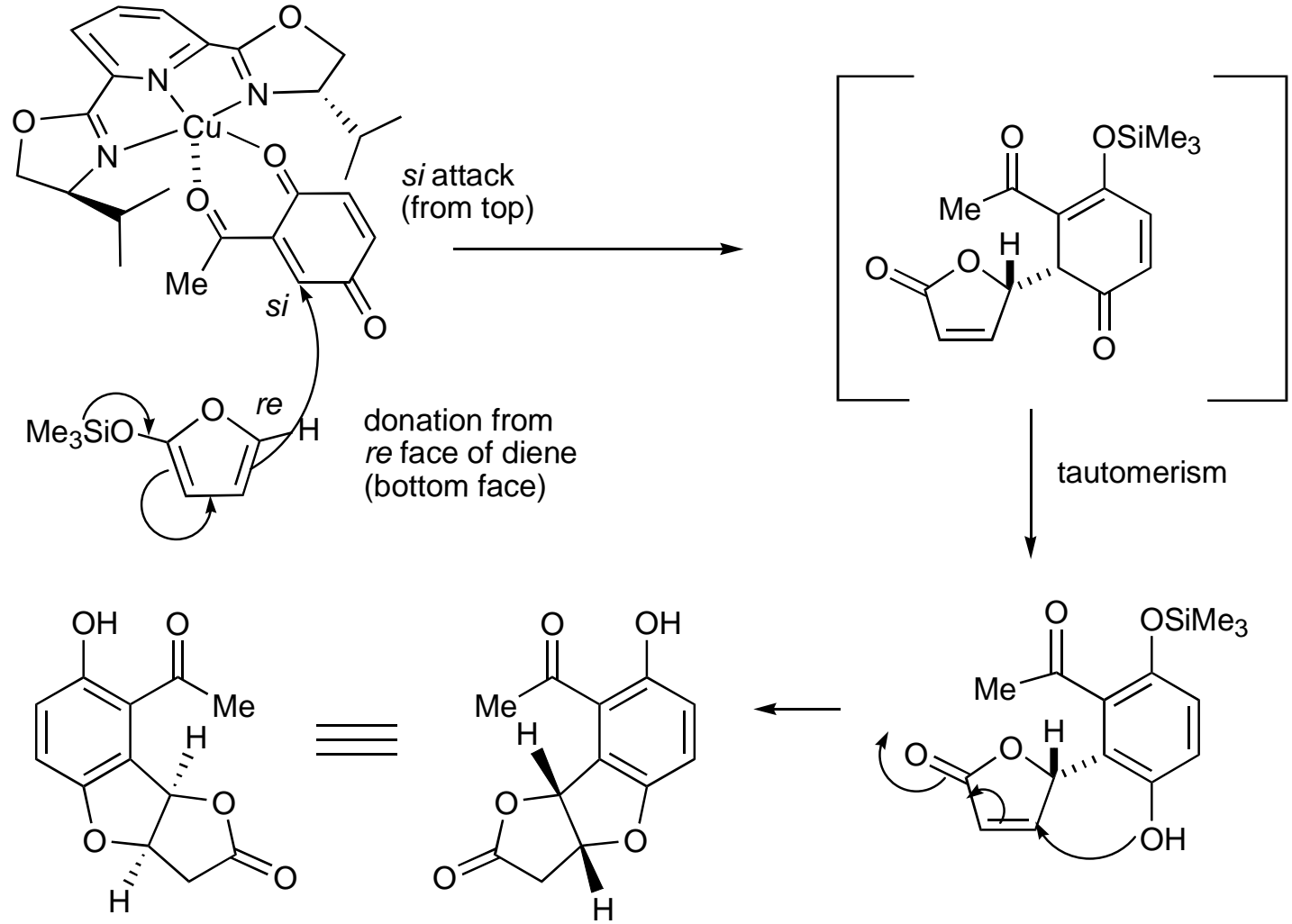


\section{Scheme 4}

In the enantioselective annulation in the presence of a stoichiometric amount of $[\mathrm{Cu}((S, S)$ valinol-pybox)](OTf $)_{2}$ ) to give furofuran 3 , it appears that the adjacent carbonyl oxygens have formed a bidentate chelate to $\mathrm{Cu}$ (II) from one face selectively, resulting in the observed ratio of $2: 1$. Under all of the reaction conditions which resulted in racemic $\mathbf{3}$, the two adjacent carbonyl oxygens presumably also formed a bidentate chelate to the Lewis acid metal centre, but conjugate addition then occurred equally from both the re face and the si face. Scheme 4 shows si face attack on the chelated enone, and donation of electrons from the re face of the diene. This si, re approach would lead to $(R, R)$-stereochemistry in the syn furobenzofuran adduct 3 . The alternative $r e$, si approach would lead to the $(S, S)$-stereochemistry.

Because of the $\mathrm{C}_{2}$ symmetry of the ligand, there is an alternative bidentate coordination which places the acetyl oxygen in the square plane (Scheme 5). Again, there are two trajectories of approach possible; Scheme 5 shows si,re interaction leading to $(R, R)$; and re,si would again afford $(S, S)$. It is assumed that the approach trajectory which minimises steric interaction with an isopropyl group is favoured, leading to $33 \%$ ee at best.
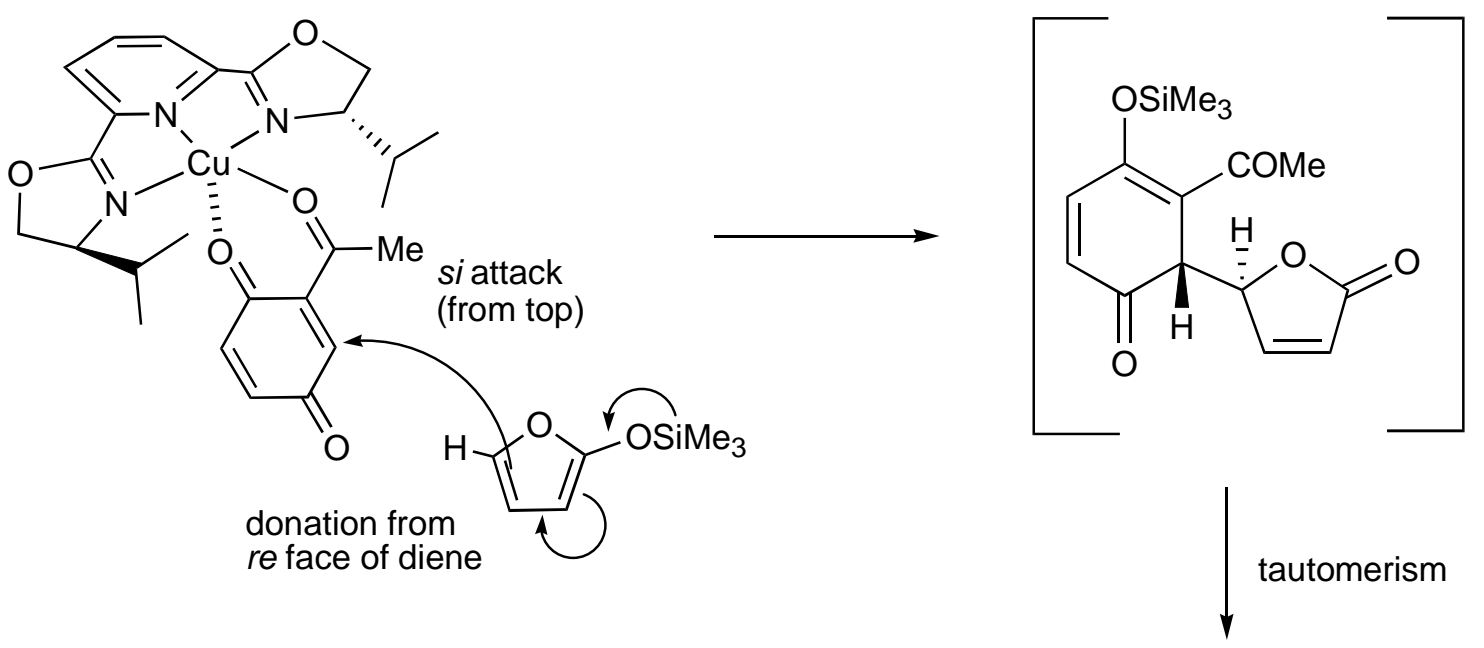<smiles>CC(=O)c1c(O)ccc2c1[C@H]1OC(=O)C[C@H]1O2</smiles>
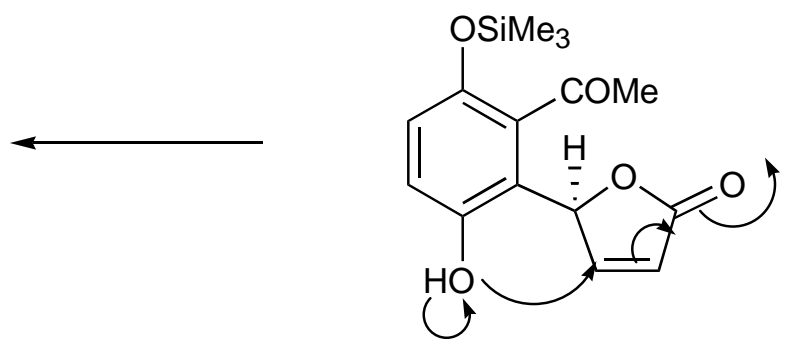

\section{Scheme 5}


In summary the work reported herein focuses on the use of bis(oxazoline)pyridine-copper(II) complexes as chiral catalysts for development of an asymmetric addition of 2[(trimethylsilyloxy)]furan to 2-acetyl-1,4-benzoquinone. The results obtained indicate that even when a stoichiometric quantity of the metal complex is used only a moderate level of enantioselectivity is observed.

\section{Experimental Section}

General Procedures. Melting points were determined using a Kofler hot-stage apparatus and are uncorrected. Optical rotations were determined on a Perkin-Elmer 341 polarimeter. Infrared spectra were recorded with a Perkin-Elmer 1600 series Fourier-transform infrared spectrometer as thin films between sodium chloride plates. ${ }^{1} \mathrm{H}$ and ${ }^{13} \mathrm{C}$ NMR spectra were recorded as indicated on either a Bruker AC200 spectrometer operating at $200 \mathrm{MHz}$ for ${ }^{1} \mathrm{H}$ nuclei and 50 $\mathrm{MHz}$ for ${ }^{13} \mathrm{C}$ nuclei, a Bruker DRX300 spectrometer operating at $300 \mathrm{MHz}$ for ${ }^{1} \mathrm{H}$ nuclei and 75 $\mathrm{MHz}$ for ${ }^{13} \mathrm{C}$ nuclei, or a Bruker DRX400 spectrometer operating at $400 \mathrm{MHz}$ for ${ }^{1} \mathrm{H}$ nuclei and $100 \mathrm{MHz}$ for ${ }^{13} \mathrm{C}$ nuclei. Both ${ }^{1} \mathrm{H}$ and ${ }^{13} \mathrm{C}$ NMR spectra were interpreted with the aid of COSY, HETCOR and DEPT 135 experiments and are reported in p.p.m. downfield from tetramethylsilane as reference. High-resolution mass spectra were recorded using a VG 7070 spectrometer operating with an ionisation potential of $70 \mathrm{eV}$ at a nominal resolution of 5000 or 10000 as appropriate. Fast atom bombardment $\left(\mathrm{FAB}^{+}\right)$spectra were recorded from $\mathrm{m}$ nitrobenzyl alcohol as matrix. Major fragments are assigned where possible and their intensities given as percentages of the base peak. Tetrahydrofuran was dried using sodium/benzophenone and distilled prior to use. Flash chromatography was performed using either Merck Kieselgel 60 or Riedel-de-Haën Kieselgel S silica gel (both 230-400 mesh), or Merck aluminum oxide (70230 mesh), with the indicated solvents. Compounds were visualized under ultraviolet light or by staining with iodine vapour or with vanillin in methanolic sulfuric acid.

2-Acetyl-1,4-benzoquinone (2). A mixture of 2,5-dihydroxyacetophenone (0.77 g, $5.0 \mathrm{mmol})$ and anhydrous sodium sulfate $(1.5 \mathrm{~g})$ in dry toluene $(10 \mathrm{~mL})$ was stirred with silver(I) oxide (2.3 g, $10.0 \mathrm{mmol}$ ) for $2.5 \mathrm{~h}$. The suspension was filtered through sodium sulfate and Celite, and the filter cake was washed with toluene. The solvent was removed under reduced pressure to afford the title compound $2(0.61 \mathrm{~g}, 80 \%)$ as dark orange crystals; m.p. $60-65^{\circ} \mathrm{C}$ (lit. ${ }^{14}$ m.p. $\left.64-65.5^{\circ} \mathrm{C}\right)$ (R)-2-Amino-2-phenylethanol (5d) (D-phenylglycinol). $\mathrm{LiBH}_{4}(0.88 \mathrm{~g}$ ) was dissolved in THF (30 mL), and chlorotrimethylsilane (10 mL, $8.624 \mathrm{~g}, 80 \mathrm{mmol}$ ) was added slowly followed by Dphenylglycine ( $3.1 \mathrm{~g}, 20 \mathrm{mmol}$ ) in one portion. The white reaction mixture was stirred at room temperature for $20.5 \mathrm{~h}$. The reaction was quenched by slow addition of $\mathrm{MeOH}$ ( $c a 20 \mathrm{~mL}$ ) until there was no more effervescence and the solution was orange. After cooling the mixture to room temperature the solvents were removed on a rotary evaporator leaving an orange oily residue. The sticky orange solid residue was dissolved in aqueous $\mathrm{NaOH}\left(50 \mathrm{~mL}, 3.6 \mathrm{~mol} \mathrm{~L}^{-1}\right)$ and extracted with dichloromethane $(3 \times 50 \mathrm{~mL})$. The yellow organic phase was dried $\left(\mathrm{Na}_{2} \mathrm{SO}_{4}\right)$ and concentrated under reduced pressure to afford a yellow solid (2.6 g, 92\%) that was recrystallized 
from ethyl acetate to afford $(R)$-2-amino-2-phenylethanol $\mathbf{5 d}(2.17 \mathrm{~g}, 78 \%)$ as colourless needles; m.p. $72-75{ }^{\circ} \mathrm{C}$ (lit. ${ }^{15}$ m.p. $\left.69-71{ }^{\circ} \mathrm{C}\right) ;[\alpha]_{\mathrm{D}}{ }^{20}=-30.4^{\circ}\left(\mathrm{c}=0.69,1 \mathrm{~mol} \mathrm{~L}^{-1} \mathrm{HCl}\right)\left(\right.$ lit. $^{15}[\alpha]_{\mathrm{D}}{ }^{24}=-32^{\circ}$ (c $\left.=0.75,1 \mathrm{~mol} \mathrm{~L}^{-1} \mathrm{HCl}\right)$.

(S)-2-Amino-3-phenylpropanol (L-Phenylalaninol) (5a). Using a procedure similar to that described above for (R)-2-amino-2-phenylethanol 5d, (S)-2-amino-3-phenylpropanol 5a was prepared from (L)-phenylalanine, lithium borohydride and chlorotrimethylsilane in $87 \%$ yield as a colourless solid; m.p 92-94 ${ }^{\circ} \mathrm{C}$; lit. m.p. ${ }^{15} 90-92{ }^{\circ} \mathrm{C}$; $[\alpha]_{\mathrm{D}}^{20}=-22.7^{\circ}\left(\mathrm{c}=1.2,1 \mathrm{~mol} \mathrm{~L}^{-1} \mathrm{HCl}\right)$ (lit. ${ }^{15}[\alpha]_{D}{ }^{24}=-22^{\circ}\left(\mathrm{c}=1.2,1 \mathrm{~mol} \mathrm{~L}^{-1} \mathrm{HCl}\right)$.

(S)-2-Amino-3-methylpentanol (L-Valinol) (5b). Using a procedure similar to that described above for $(R)$-2-amino-2-phenylethanol 5d, (S)-2-amino-3-methylbutanol $\mathbf{5 b}$ was prepared from (L)-valine, lithium borohydride and chlorotrimethylsilane in $87 \%$ yield as a colourless thick viscous oil; $[\alpha]_{D}^{20}=+16.7^{\circ}\left(\mathrm{c}=10.0\right.$, EtOH) (lit. ${ }^{15}[\alpha]_{\mathrm{D}}{ }^{24}=+17^{\circ}(\mathrm{c}=10.0$, EtOH).

(S)-3-Methyl-2-aminopentanol (L-Isoleucinol) (5c). Using a procedure similar to that described above for (R)-2-amino-2-phenylethanol 5d, (S)-3-methyl-2-aminopentanol 5c was prepared from (L)-isoleucine, lithium borohydride and chlorotrimethylsilane in $84 \%$ yield as a colourless oil; b.p $115{ }^{\circ} \mathrm{C} / 15 \mathrm{mmHg}$; lit. b.p. ${ }^{15} 100-101{ }^{\circ} \mathrm{C} / 5 \mathrm{mmHg} ;[\alpha]_{\mathrm{D}}{ }^{20}=+3.8^{\circ}$ (c $=0.98$, EtOH) (lit. ${ }^{15}[\alpha]_{\mathrm{D}}{ }^{24}=+3.5^{\circ}(\mathrm{c}=1.0$, EtOH).

Pyridine-2,6-dicarbonyl dichloride. ${ }^{16,17}$ Pyridine-2,6-dicarboxylic acid (3.05 g, 17.9 mmol) was dissolved in thionyl chloride $(20 \mathrm{~mL})$ and the mixture heated at reflux for $8 \mathrm{~h}$ using a Liebig condenser fitted with a $\mathrm{CaCl}_{2}$ drying tube. After leaving the mixture to stand overnight, the excess thionyl chloride was removed by distillation. The residue was placed under high vacuum for several hours to afford pyridine-2,6-dicarbonyl dichloride (3.63 g, 99\%) as pale cream crystals; m.p. 132-137 ${ }^{\circ} \mathrm{C}$; (Found: $\mathrm{M}^{+}$, 202.9537, $\mathrm{C}_{7} \mathrm{H}_{3}{ }^{35} \mathrm{Cl}_{2} \mathrm{NO}_{2}$ requires 202.9541; 204.9508, $\mathrm{C}_{7} \mathrm{H}_{3}{ }^{35} \mathrm{Cl}^{37} \mathrm{ClNO}_{2}$ requires 204.9511; 206.9481, $\mathrm{C}_{7} \mathrm{H}_{3}{ }^{37} \mathrm{Cl}_{2} \mathrm{NO}_{2}$ requires 206.9482); $v_{\max }$ (film) $/ \mathrm{cm}^{-1} 1755(\mathrm{C}=\mathrm{O}), 876(\mathrm{C}-\mathrm{Cl}) ; \delta_{\mathrm{H}}\left(200 \mathrm{MHz}, \mathrm{CDCl}_{3}\right) 8.23(1 \mathrm{H}, \mathrm{t}, J 7.3 \mathrm{~Hz}, \mathrm{H} 4), 8.43(2 \mathrm{H}$, d, $J$ 7.4 Hz, H3, H5); $\delta_{\mathrm{C}}\left(50 \mathrm{MHz}, \mathrm{CDCl}_{3}\right) 129.0$ (C-3, C-5), 139.4 (C-4). m/z 207 (M+10\%), $205\left(\mathrm{M}^{+}, 56 \%\right), 203\left(\mathrm{MH}^{+}, 86 \%\right), 170\left(207-{ }^{37} \mathrm{Cl}, 33 \%\right), 168\left(203-{ }^{35} \mathrm{Cl}, 100 \%\right), 142$ (170-CO, 34\%), 140 (168-CO, 34\%), 114 (142-CO, 7\%), 112 (140-CO, 21\%), 76( $\left.\mathrm{C}_{5} \mathrm{H}_{5} \mathrm{~N}^{+}\right), 63\left(\mathrm{CO}^{35} \mathrm{Cl}\right.$, $10 \%)$.

$N, N$ '-Bis[(R)-2-hydroxy-1-phenylethyl)]pyridine-2,6-dicarboxamide (6d). (R)-2-Amino-2phenylethanol 5d (D-phenylglycinol) $(1.0 \mathrm{~g}, 7.30 \mathrm{mmol})$ was added to a solution of potassium hydrogencarbonate $(0.78 \mathrm{~g}, 7.82 \mathrm{mmol})$ in $\mathrm{H}_{2} \mathrm{O}(5.2 \mathrm{~mL})$. Isopropyl acetate $(10 \mathrm{~mL})$ and ethyl acetate $(14 \mathrm{~mL})$ were mixed together and added. The resulting colourless mixture was heated to 60-70 ${ }^{\circ} \mathrm{C}$. Pyridine-2,6-dicarbonyl dichloride $(0.75 \mathrm{~g}, 3.68 \mathrm{mmol})$ was dissolved in chloroform $(4.5 \mathrm{~mL})$ and this solution was added dropwise via syringe over $5 \mathrm{~min}$. The mixture was heated under reflux for $2.5 \mathrm{~h}$, then left to cool with stirring overnight. The aqueous phase was extracted with ethyl acetate $(2 \times 35 \mathrm{~mL})$, and the combined organic phases were dried $\left(\mathrm{Na}_{2} \mathrm{SO}_{4}\right)$ and evaporated under reduced pressure to give the title bisamide $\mathbf{6 d}(1.45 \mathrm{~g}$. 98\%) as a colourless foamy solid; m.p. $72-75{ }^{\circ} \mathrm{C}$; $[\alpha]_{\mathrm{D}}{ }^{20}=-30.4^{\circ}\left(\mathrm{c}=0.69,1 \mathrm{M} \mathrm{HCl}\right.$ ); (Found: $\mathrm{MH}^{+}$, 406.1770, $\mathrm{C}_{23} \mathrm{H}_{24} \mathrm{~N}_{3} \mathrm{O}_{4}$ requires 406.1769); $v_{\max }(\mathrm{film}) / \mathrm{cm}^{-1} 3435(\mathrm{OH}), 1692$ (amide $\left.\mathrm{CONH}\right) ; \delta_{\mathrm{H}}(200$ $\left.\mathrm{MHz} \mathrm{CDCl}_{3}\right) 2.17(1 \mathrm{H}, \mathrm{s}, \mathrm{OH}), 3.42$ (2H, bs, $\left.\mathrm{H}-1^{\prime}\right), 5.25$ (1H, apparent doublet, H-2'), 7.2-7.4 
(10H, m, Ph), 7.85 (1H, t, J 7.7, H-4), 8.18 (1H, d, J 7.7, H-4), 8.87 (1H, d, J 7.5, NH); $\delta_{\mathrm{C}}(50$ $\left.\mathrm{MHz}_{\mathrm{CDCl}}\right) 55.8(\mathrm{CH}, \mathrm{CHN}), 65.9\left(\mathrm{CH}_{2}, \mathrm{CH}_{2} \mathrm{OH}\right), 125.1(\mathrm{CH}, \mathrm{C}-3), 126.7$ (CH, C-2'), 127.8 (CH, C-4'), 128.8 (CH, C-3'), 138.8 (C, Ph), 139.0 (CH, C-4), 148.5 (C, C-2), 163.8 (C, C=O); m/z $406\left(\mathrm{MH}^{+}, 4 \%\right), 388\left(\mathrm{MH}^{+}-\mathrm{H}_{2} \mathrm{O}, 3.4 \%\right), 372$ (388-O, 18\%), $370\left(\mathrm{MH}^{+}-2 \mathrm{H}_{2} \mathrm{O}, 27 \%\right), 268$ $\left(\mathrm{MH}^{+}-\mathrm{C}_{8} \mathrm{H}_{10} \mathrm{ON}, 34 \%\right), 250\left(268-\mathrm{H}_{2} \mathrm{O}, 17 \%\right), 120\left(\mathrm{C}_{8} \mathrm{H}_{9} \mathrm{O}, 100 \%\right) 106\left(\mathrm{C}_{6} \mathrm{H}_{9} \mathrm{ON}\right)$.

2,6-Bis[(4R)-4,5-dihydro-4-phenyl-2-oxazolyl)]pyridine (4d). ${ }^{9,10}$ Thionyl chloride (2.4 mL, 3.9 g, $33.05 \mathrm{mmol})$ was added with stirring to a solution of $N, N$-bis[(R)-2-hydroxy-1phenylethyl)]pyridine-2,6-dicarboxamide 6d (1.34 g, $3.30 \mathrm{mmol})$ in chloroform $(20 \mathrm{~mL})$. The mixture was heated under reflux for $3 \mathrm{~h}$, then cooled in ice. Water was added through the top of the condenser to quench the excess thionyl chloride and the aqueous layer was extracted with dichloromethane ( 2 x $25 \mathrm{~mL}$ ). The combined organic phases were washed with saturated aqueous $\mathrm{NaHCO}_{3}(10-15 \mathrm{~mL})$ and brine $(10-15 \mathrm{~mL})$, and then dried $\left(\mathrm{Na}_{2} \mathrm{SO}_{4}\right)$. The solvent was removed at reduced pressure to give 2,6-bis[(4R)-4,5-dihydro-4-phenyl-2-oxazolyl)]pyridine dihydrochloride as a pale brown solid (1.43 g, 97\%); $v_{\max }(\mathrm{film}) / \mathrm{cm}^{-1} 3325(\mathrm{NH}), 1656(\mathrm{C}=\mathrm{N})$, $1527(\mathrm{C}=\mathrm{C})$.

The bis(hydrochloride) salt (1.43 g, $3.2 \mathrm{mmol}$ ) was dissolved in $\mathrm{MeOH}$ (approx. $25 \mathrm{~mL}$ ) and treated with aqueous $\mathrm{NaOH}\left(8.4 \mathrm{~mL}, 3 \mathrm{~mol} \mathrm{~L}^{-1}\right)$, affording a cloudy orange-light brown solution. The mixture was stirred at room temperature under a nitrogen atmosphere for $73 \mathrm{~h}$, and then extracted with dichloromethane $(2 \times 50 \mathrm{~mL})$. The organic phase was dried $\left(\mathrm{Na}_{2} \mathrm{SO}_{4}\right)$ and the solvents removed under reduced pressure to afford a creamy-yellow solid that was dissolved in hot (near boiling) ethyl acetate, assisted with a small quantity of $\mathrm{MeOH}$. Hexane was added, and the flask was left to cool to room temperature then placed in a refrigerator for at least $1 \mathrm{~h}$. The resultant colourless crystals were filtered off, and washed with cold ethyl acetate and cold hexanes to give 2,6-bis[(4R)-4,5-dihydro-4-phenyl-2-oxazolyl)]pyridine 4d (1.04 g, 89\%), m.p. 168-70 ${ }^{\circ} \mathrm{C}$; lit. ${ }^{10}$ m.p. $170-172{ }^{\circ} \mathrm{C}$; $[\alpha]_{\mathrm{D}}{ }^{20}=+180.3^{\circ}\left(\mathrm{c}=1.0, \mathrm{CH}_{2} \mathrm{Cl}_{2}\right)$; lit. $^{10}[\alpha]_{\mathrm{D}}{ }^{20}=+183.5^{\circ}(\mathrm{c}=$ 1.03, $\mathrm{CH}_{2} \mathrm{Cl}_{2}$ ); (Found: $\mathrm{MH}^{+} 370.1551, \mathrm{C}_{23} \mathrm{H}_{20} \mathrm{~N}_{3} \mathrm{O}_{2}$ requires 370.1556); $v_{\max }(\mathrm{film}) / \mathrm{cm}^{-1} 1651$ $(\mathrm{C}=\mathrm{N}), 1568(\mathrm{C}=\mathrm{C}) ; \delta_{\mathrm{H}}(200 \mathrm{MHz}) 4.41$ and $4.45\left(2 \mathrm{H}\right.$, dd, $J 8.5$ and $\left.9.5 \mathrm{~Hz}, \mathrm{H}-5{ }_{\mathrm{B}}\right), 4.91$ and 4.96 (2H, dd, $J 10.4$ and 10.1, H-5' $\left.{ }_{\mathrm{A}}\right), 5.46$ (1H, apparent t, $J$ 9.5, H-4'), 7.26-7.41 (10H, m, Ph), $7.93(1 \mathrm{H}, \mathrm{t}, J 7.8 \mathrm{~Hz}, \mathrm{H}-4), 8.34\left(1 \mathrm{H}, \mathrm{d}, J\right.$ 7.8, H3 and H5); $\delta_{\mathrm{C}}(50 \mathrm{MHz}) 70.3\left(\mathrm{CH}, \mathrm{C}-4{ }^{\prime}\right)$, 75.5( $\mathrm{CH}_{2}, \mathrm{C}-5$ '), 126.3 (CH, C-3), 126.8 (CH, C-2"), 127.8 (CH, C-4"), 128.8 (CH, C-3"), 137.5 (CH, C-4), 141.6 (C, Ph), 146.6 (C, C-2), 163.4 (C, C-2'); m/z 761 (2M+Na) ${ }^{+}, 739(2 \mathrm{M}+\mathrm{H})$, 392(M+Na) $)^{+}, 370\left(\mathrm{MH}^{+}, 100 \%\right), 250\left(\mathrm{M}-\mathrm{C}_{8} \mathrm{H}_{8} \mathrm{O}\right), 223\left(\mathrm{M}-\mathrm{C}_{9} \mathrm{H}_{9} \mathrm{ON}, 7 \%\right)$.

$N, N^{\prime}$-bis[(S)-(2-hydroxy-1-(phenylmethyl)ethyl)]pyridine-2,6-dicarboxamide (6a). Using a procedure similar to that described above for bisamide $\mathbf{6 d}$, bisamide $\mathbf{6 a}$ was prepared from pyridine-2,6-dicarbonyl chloride (0.66 g, $3.2 \mathrm{mmol})$ and (L)-phenylalaninol 5a (1.0 g, $6.6 \mathrm{mmol})$ in $94 \%$ yield as a colourless solid; m.p. 98-100 ${ }^{\circ} \mathrm{C}$; (Found: $\mathrm{M}^{+}$, 433.1997, $\mathrm{C}_{25} \mathrm{H}_{27} \mathrm{~N}_{3} \mathrm{O}_{4}$, requires 433.2002); $v_{\max }$ (film)/cm $3323(\mathrm{OH}, \mathrm{NH}), 1649$ (amide CONH); $\delta_{\mathrm{H}}\left(200 \mathrm{MHz}, \mathrm{CDCl}_{3}\right) 2.35$ (2H, bs, OH), 3.02 (4H, d, J 7.1, $\left.\mathrm{CH}_{2} \mathrm{Ph}\right), 3.71-3.87$ (4H, m, $\left.\mathrm{CH}_{2} \mathrm{O}\right), 4.32-4.42$ (2H, m, CHN), 7.19-7.36 (10H, m, Ph), 7.95-8.02 (3H, m, H-4 and NH), $8.29\left(2 \mathrm{H}, \mathrm{d}, J\right.$ 7.9, H-3); $\delta_{\mathrm{c}}(50 \mathrm{MHz}$, $\left.\mathrm{CDCl}_{3}\right) 37.0\left(\mathrm{CH}_{2}, \mathrm{CH}_{2} \mathrm{Ph}\right), 53.0(\mathrm{CH}, \mathrm{CHN}), 63.8\left(\mathrm{CH}_{2}, \mathrm{CH}_{2} \mathrm{O}\right), 125.1(\mathrm{CH}, \mathrm{C}-3), 126.8(\mathrm{CH}$, Ph), 128.7 (CH, Ph), 129.3 (CH, Ph), 137.5 (C, Ph), 139.1 (CH, C-4), 148.5 (C, C-2), 163.7 (C, 
$\mathrm{C}=\mathrm{O}) ; \mathrm{m} / \mathrm{z} 433\left(\mathrm{M}^{+}, 2\right.$ \%), $342\left(\mathrm{M}-\mathrm{C}_{7} \mathrm{H}_{7}, 100\right), 324\left(342-\mathrm{H}_{2} \mathrm{O}, 40\right), 306$ (324- $\left.\mathrm{H}_{2} \mathrm{O}, 12\right), 237$ (306$\left.\mathrm{C}_{5} \mathrm{H}_{9}, 8\right)$.

2,6-Bis[(4S)-4,5-dihydro-4-(phenylmethyl)-2-oxazolyl $]$ pyridine (4a). ${ }^{18,19}$ Using a procedure similar to that described above for the preparation of phenyl pybox $4 \mathbf{d d}$ from bisamide $\mathbf{6 d}$, bisamide 6a was treated with thionyl chloride to afford 2,6-bis[(4S)-4,5-dihydro-4(phenylmethyl)-2-oxazolyl]pyridine hydrochloride (1.76 g, 78\%) as a colourless solid; m.p. 135$136{ }^{\circ} \mathrm{C} ; v_{\max }(\mathrm{film}) / \mathrm{cm}^{-1} 3310(\mathrm{NH}), 1673(\mathrm{C}=\mathrm{N}) ; \delta_{\mathrm{H}}\left(400 \mathrm{MHz}, \mathrm{CDCl}_{3}\right)$ 3.06-3.16 (4H, m, $\mathrm{CH}_{2} \mathrm{Ph}$ ), 3.70 (2H, dd, $J$ 2.9, and $J$ 11.3, H-5'A), 3.81 (2H, dd, $J$ 3.9, and $J$ 11.3, H-5'B), 4.684.74 (2H, m, H-4'), 7.27-7.38 (10H, m, Ph), 8.05-8.11 (3H, m, H-4 and NH), 8.37 (2H, d, J 7.8, $\mathrm{H}-3) ; \delta_{\mathrm{C}}\left(50 \mathrm{MHz}, \mathrm{CDCl}_{3}\right) 37.6\left(\mathrm{CH}_{2}, \mathrm{CH}_{2} \mathrm{Ph}\right), 46.8\left(\mathrm{CH}_{2}, \mathrm{C}-5^{\prime}\right), 50.8\left(\mathrm{CH}, \mathrm{C}-4^{\prime}\right), 125.1(\mathrm{CH}, \mathrm{C}-$ 3), 127.1 (CH, Ph), 128.8 (CH, Ph), 129.3 (CH, Ph), 136.7 (CH, C-4), 139.2 (C, Ph), 148.4 (C, C2), $162.7\left(\mathrm{C}, \mathrm{C}-2^{\prime}\right) ; \mathrm{m} / \mathrm{z}(\mathrm{FAB}+), 470\left(\mathrm{MH}^{+}, 50 \%\right), 434(\mathrm{M}-\mathrm{HCl}, 2), 378\left(\mathrm{M}-\mathrm{C}_{6} \mathrm{H}_{6} \mathrm{~N}, 10\right), 168$ (226- $\mathrm{C}_{3} \mathrm{H}_{8} \mathrm{~N}$, 13). The bis(hydrochloride) salt was then treated with $\mathrm{NaOH}$ in $\mathrm{MeOH}$ for 3 days (as described above for phenyl pybox 4d) to give 2,6-bis[(4S)-4,5-dihydro-4-(phenylmethyl)-2oxazolyl]pyridine 4a $(0.91 \mathrm{~g}, 71 \%)$ as colourless crystals, m.p. $155-157{ }^{\circ} \mathrm{C}$; lit. ${ }^{18}$ m.p. $156{ }^{\circ} \mathrm{C}$; $[\alpha]_{\mathrm{D}}{ }^{25}=-37.3^{\circ}\left(\mathrm{c}=0.66, \mathrm{CHCl}_{3}\right)$; lit. ${ }^{19}[\alpha]_{\mathrm{D}}{ }^{25}=-38^{\circ}\left(\mathrm{c}=0.67, \mathrm{CHCl}_{3}\right.$ ); (Found: $\mathrm{M}^{+}, 397.1792$, $\mathrm{C}_{25} \mathrm{H}_{23} \mathrm{~N}_{3} \mathrm{O}_{2}$, requires 397.1790); $\delta_{\mathrm{H}}\left(200 \mathrm{MHz}, \mathrm{CDCl}_{3}\right) 2.74(2 \mathrm{H}$, dd, $J 8.8$ and $J$ 13.7, $\mathrm{CH}_{\mathrm{A}} \mathrm{H}_{\mathrm{B}} \mathrm{Ph}$ ), 3.26 (2H, dd, $J 5.1$ and $J$ 13.7, $\mathrm{CH}_{\mathrm{A}} \mathrm{H}_{\mathrm{B}} \mathrm{Ph}$ ), 4.25 (2H, dd, $J 7.8$ and $J$ 8.6, H-5'A), 4.45 (2H, t, J 8.3, H-5'B), 4.60-4.73 (2H, m, H-4'), 7.17-7.35 (10H, m, Ph), 7.87 (1H, dd, J 7.5 and $J$ 8.2, H-4), 8.21 (2H, d, $J$ 7.8, H-3); $\delta_{\mathrm{C}}\left(50 \mathrm{MHz}, \mathrm{CDCl}_{3}\right) 41.5\left(\mathrm{CH}_{2}, \mathrm{CH}_{2} \mathrm{Ph}\right), 68.0(\mathrm{CH}, \mathrm{C}-$ 4'), $72.4\left(\mathrm{CH}_{2}, \mathrm{C}-5^{\prime}\right), 125.7$ (CH, C-3), 126.5 (CH, Ph), 128.5 (CH, Ph), 129.1 (CH, Ph), 137.2 (CH, C-4), 137.6 (C, Ph), 146.7 (C, C-2), 162.6 (C, C-2'); m/z 397 (M+1 $10 \%$ ), 306 (M-C ${ }_{7} \mathrm{H}_{7}$, 100), 278 (306-CO, 11), $214\left(306-\mathrm{C}_{6} \mathrm{H}_{6} \mathrm{~N}, 8\right)$. The ${ }^{1} \mathrm{H}$ and ${ }^{13} \mathrm{C}$ NMR data were in agreement with the literature values. ${ }^{18}$

$N, N^{\prime}$-bis[(S)-(1-hydroxymethyl-2-methylpropyl)]pyridine-2,6-dicarboxamide (6b). ${ }^{20}$ Using a procedure similar to that described above for bisamide $\mathbf{6 d}$, bisamide $\mathbf{6 b}$ was prepared from pyridine-2,6-dicarbonyl dichloride (3.4 g, $16.7 \mathrm{mmol}$ ) and (L)-valinol $5 \mathbf{b}$ (3.45 g, $33.4 \mathrm{mmol}$ ) in 97\% yield as a colourless solid, m.p. 83-85 ${ }^{\circ} \mathrm{C}$; (Found: $\mathrm{M}^{+}$, 337.2002, $\mathrm{C}_{17} \mathrm{H}_{27} \mathrm{~N}_{3} \mathrm{O}_{4}$, requires 337.2002); $v_{\max }$ (film)/ $\mathrm{cm}^{-1} 3311\left(\mathrm{OH}\right.$ and $\mathrm{NH}$ ), 1647 (amide $\mathrm{CONH}$ ); $\delta_{\mathrm{H}}\left(200 \mathrm{MHz}, \mathrm{CDCl}_{3}\right.$ ) 1.03 (6H, d, J 4.4, $\left.\mathrm{CH}_{3}\right), 1.06$ (6H, d, $J$ 4.4, $\left.\mathrm{CH}_{3}\right), 2.03-2.25$ [4H, m, OH and $\left.\mathrm{CH}\left(\mathrm{CH}_{3}\right)_{2}\right], 3.84$ (4H, d, $J$ 4.6, $\mathrm{CH}_{2} \mathrm{OH}$ ), 3.90-4.00 (2H, m, H-1'), 8.01-8.08 (3H, m, H-4 and NH), 8.34 (2H, d, $J$ 7.8, H-3); $\delta_{\mathrm{C}}\left(50 \mathrm{MHz}, \mathrm{CDCl}_{3}\right) 18.6\left(\mathrm{CH}_{3}\right), 19.7\left(\mathrm{CH}_{3}\right), 29.3\left[\mathrm{CH}, \mathrm{CH}\left(\mathrm{CH}_{3}\right)_{2}\right], 57.2(\mathrm{CH}, \mathrm{CHN})$, $63.9\left(\mathrm{CH}_{2}, \mathrm{CH}_{2} \mathrm{O}\right), 125.1$ (CH, C-3), 139.3 (CH, C-4), 148.7 (C, C-2), $164.1(\mathrm{C}=\mathrm{O})$; m/z $337\left(\mathrm{M}^{+}\right.$, 2 \%), $322\left(\mathrm{M}-\mathrm{CH}_{3}, 3\right.$ \%), $306\left(\mathrm{M}-\mathrm{CH}_{2} \mathrm{OH}, 100\right), 294\left(\mathrm{M}-\mathrm{C}_{3} \mathrm{H}_{7}, 29\right), 288\left(306-\mathrm{H}_{2} \mathrm{O}, 25\right), 220$ $\left(288-\mathrm{C}_{4} \mathrm{H}_{6} \mathrm{~N}, 15\right)$.

2,6-Bis[(4S)-4,5-dihydro-4-(1-methylethyl)-2-oxazolyl]pyridine (4b). Using a procedure similar to that described above for the preparation of phenyl pybox $4 \mathbf{d}$ from bisamide $\mathbf{6 d}$, bisamide 6b (5.47 g, $1.6 \mathrm{mmol}$ ) was treated with thionyl chloride to afford 2,6-bis[(4S)-4,5dihydro-4-(1-methylethyl)-2-oxazolyl]pyridine hydrochloride (4.38 g, 70\%) as a cream solid. The bis(hydrochloride) salt was treated immediately with $\mathrm{NaOH}$ in $\mathrm{MeOH}$ for 3 days (as described above for phenyl pybox 4d) to give 2,6-bis[(4S)-4,5-dihydro-4-(1-methylethyl)-2- 
oxazolyl]pyridine $\mathbf{4 b}$ (3.24 g, 64\%) as colourless needles, m.p. 151-153 ${ }^{\circ} \mathrm{C}$; lit. $^{20}$ m.p. 151-154 ; $[\alpha]_{\mathrm{D}}{ }^{25}=-117.4^{\circ},\left(\mathrm{c}=0.7, \mathrm{CH}_{2} \mathrm{Cl}_{2}\right)$; lit. $^{10}[\alpha]_{\mathrm{D}}{ }^{25}=-116.8^{\circ},\left(\mathrm{c}=1.0, \mathrm{CH}_{2} \mathrm{Cl}_{2}\right)$; $\left(\right.$ Found: $\mathrm{M}^{+}$ 301.1787, $\mathrm{C}_{17} \mathrm{H}_{23} \mathrm{~N}_{3} \mathrm{O}_{2}$, requires 301.1790); $v_{\max }(\mathrm{film}) / \mathrm{cm}^{-1} 1636(\mathrm{C}=\mathrm{N}) ; \delta_{\mathrm{H}}\left(200 \mathrm{MHz}, \mathrm{CDCl}_{3}\right)$ 0.94 (6H, d, $J$ 6.7, $\left.\mathrm{CH}_{3}\right), 1.05$ (6H, d, J 6.7, $\left.\mathrm{CH}_{3}\right), 1.83-1.93\left(2 \mathrm{H}, \mathrm{m}, \mathrm{CHCH}_{3}\right), 4.08-4.27(4 \mathrm{H}, \mathrm{m}$, H-5'A and H-4'), 4.54 (2H, dd, $J 7.8$ and $J$ 8.8, H-5'B), 7.86 (1H, t, $J$ 7.8, H-4), 8.21 (2H, d, $J$ 7.8, $\mathrm{H}-3) ; \delta_{\mathrm{C}}\left(50 \mathrm{MHz}, \mathrm{CDCl}_{3}\right) 18.3\left(\mathrm{CH}_{3}\right), 19.0\left(\mathrm{CH}_{3}\right), 32.8\left(\mathrm{CH}, \mathrm{CHCH}_{3}\right), 71.0\left(\mathrm{CH}, \mathrm{C}-4^{\prime}\right), 73.0$ $\left(\mathrm{CH}_{2}, \mathrm{C}-5^{\prime}\right), 125.7$ (CH, C-3), 137.2 (CH, C-4), 146.9 (C, C-2), 162.2 (C, C-2'); m/z 301 (M ${ }^{+}, 3$ \%), $286\left(\mathrm{M}-\mathrm{CH}_{3}, 2 \%\right) 258\left(\mathrm{M}-\mathrm{C}_{3} \mathrm{H}_{7}, 100\right), 230\left(\mathrm{M}-\mathrm{C}_{3} \mathrm{H}_{7} \mathrm{CO}, 22\right)$.

$N, N^{\prime}$-bis[(S)-(1-hydroxymethyl-2-methylbutyl)]pyridine-2,6-dicarboxamide (6c). Using a procedure similar to that described above for bisamide $\mathbf{6 d}$, bisamide $\mathbf{6 c}$ was prepared from pyridine-2,6-dicarbonyl chloride $(0.87 \mathrm{~g}, 4.9 \mathrm{mmol})$ and (L)-isoleucinol 5c (1.03 g, $8.5 \mathrm{mmol})$ in 91\% yield as a foamy solid; m.p. $90-95{ }^{\circ} \mathrm{C}$; $[\alpha]_{\mathrm{D}}{ }^{20}=-77.2^{\circ}$ (c = 0.94, EtOH); (Found: $\mathrm{MH}^{+}$ 366.23928, $\mathrm{C}_{19} \mathrm{H}_{32} \mathrm{~N}_{3} \mathrm{O}_{4}$ requires 366.23928); $v_{\max }\left(\right.$ film) $/ \mathrm{cm}^{-1} 3721(\mathrm{OH}$ and $\mathrm{NH}), 1690$ (amide $\mathrm{CONH}) ; \delta_{\mathrm{H}}\left(200 \mathrm{MHz}, \mathrm{CDCl}_{3}\right)$ 0.94-0.98 (12H, m, $\left.\mathrm{CH}_{2} \mathrm{CH}_{3}, \mathrm{CHCH}_{3}\right), 1.40-1.80(6 \mathrm{H}, \mathrm{m}$, $\left.\mathrm{CHMe}, \mathrm{CH}_{2} \mathrm{Me}\right), 3.78$ (4H, m, $\left.\mathrm{CH}_{2} \mathrm{OH}\right), 4.24$ (2H, m, CHN), 8.0 (1H, t, J 7.8 Hz, H4), 8.1 (2H, d, J 7.7 Hz, NH), 8.29 (2H, d, J 7.7 Hz, H3, H5); $\delta_{\mathrm{C}}\left(200 \mathrm{MHz}, \mathrm{CDCl}_{3}\right) 22.3\left(\mathrm{CH}_{3}\right), 23.0\left(\mathrm{CH}_{3}\right)$, $25.0\left(\mathrm{CH}, \mathrm{C}_{4} \mathrm{H}_{9}\right), 40.1\left(\mathrm{CH}_{2}, \mathrm{CH}_{2} \mathrm{CH}_{3}\right), 50.1(\mathrm{CH}, \mathrm{CHN}), 65.5\left(\mathrm{CH}_{2}, \mathrm{CH}_{2} \mathrm{OH}\right), 125.0(\mathrm{CH}, \mathrm{C}-3)$, 139.0 (CH, C-4), 149.1 (C, C-2), 163.3 (C=O); m/z 366 ( $\left.\mathrm{MH}^{+}, 100 \%\right), 334\left(\mathrm{M}^{+}-\mathrm{CH}_{2} \mathrm{OH}, 15 \%\right)$.

2,6-Bis[(4S)-4,5-dihydro-4-(2-methylpropyl)-2-oxazolyl $]$ pyridine (4c). Using a procedure similar to that described above for the preparation of phenyl pybox 4d from bisamide $6 \mathbf{d}$, bisamide 6c was treated with thionyl chloride to afford 2,6-bis[(4S)-4,5-dihydro-4-(2methylpropyl)-2-oxazolyl]pyridine hydrochloride as a cream solid; $v_{\max }(\mathrm{film}) / \mathrm{cm}^{-1} 3495$ (NH), 1660 (C=N); (Found: $\mathrm{MH}^{+}$402.1708, $\mathrm{C}_{19} \mathrm{H}_{30}{ }^{35} \mathrm{Cl}_{2} \mathrm{~N}_{2} \mathrm{O}_{3}$ requires 402.1715; $\mathrm{MH}^{+}$404.1682, $\mathrm{C}_{19} \mathrm{H}_{30}{ }^{35} \mathrm{Cl}^{37} \mathrm{Cl} \mathrm{N} \mathrm{N}_{2} \mathrm{O}_{3}$ requires 404.1686; $\mathrm{MH}^{+}$406.1672, $\mathrm{C}_{19} \mathrm{H}_{30}{ }^{37} \mathrm{Cl}_{2} \mathrm{~N}_{2} \mathrm{O}_{3}$ requires 406.1656). The bis(hydrochloride) salt was then treated with $\mathrm{NaOH}$ in $\mathrm{MeOH}$ for 3 days (as described above for phenyl pybox 4d) to give 2,6-bis[(4S)-4,5-dihydro-4-(2-methylpropyl)-2-oxazolyl]pyridine 4c in $44 \%$ overall yield, m.p. $115-118{ }^{\circ} \mathrm{C} ;[\alpha]_{\mathrm{D}}{ }^{20}=-144.1^{\circ}\left(\mathrm{c}=0.07, \mathrm{CDCl}_{3}\right.$ ); (Found: $\mathrm{M}^{+}$, 329.2104, $\mathrm{C}_{19} \mathrm{H}_{27} \mathrm{~N}_{3} \mathrm{O}_{2}$ requires 329.2103); $v_{\max }(\mathrm{film}) / \mathrm{cm}^{-1} 1637(\mathrm{C}=\mathrm{N}) ; \delta_{\mathrm{H}}\left(200 \mathrm{MHz}, \mathrm{CDCl}_{3}\right)$ $1.00\left(12 \mathrm{H}\right.$, d and t, $J 7.0 \mathrm{~Hz}, \mathrm{CH}_{2} \mathrm{CH}_{3}$ and $\left.\mathrm{CHCH}_{3}\right), 1.24-1.42\left(1 \mathrm{H}, \mathrm{m}, \mathrm{CH}_{2} \mathrm{CH}_{3}\right), 1.66-1.89(3 \mathrm{H}$, m, $\mathrm{CHCH}_{3}$ ), 4.05-4.14 (1H, apparent t, $J$ 13.95, H-5'A), 4.40 (2H, m, H-4'), 4.57-4.66 (1H, dd, $J$ 7.85 and 7.95, H-5'B), 7.86 (1H, dd, $J$ 8.2, $7.3 \mathrm{~Hz}, \mathrm{H}-4), 8.14$ (2H, d, J 7.6, H-3, H-5); $\delta_{\mathrm{C}}(200$ $\left.\mathrm{MHz}, \mathrm{CDCl}_{3}\right) 22.7\left(\mathrm{CH}_{3}\right), 25.3\left(\mathrm{CH}_{3}\right), 45.4\left(\mathrm{CH}_{2}, \mathrm{CH}_{2} \mathrm{CH}_{3}\right), 65.2(\mathrm{CH}, \mathrm{C}-4), 73.8\left(\mathrm{CH}_{2}, \mathrm{C}-5\right.$ '), 125.5 (CH, C-3), 137.3 (CH, C-5), 147.2 (C, C-2), 162.1 (C, C-2'); m/z 329 (M+ , 47\%), 314 (M$\left.\mathrm{CH}_{3}, 16 \%\right), 286$ (314- C=O, 10\%), $272\left(\mathrm{M}-\mathrm{C}_{4} \mathrm{H}_{9}, 100 \%\right), 57\left(\mathrm{C}_{4} \mathrm{H}_{9}, 9 \%\right)$.

(3aR*,8bR*)-8-Acetyl-3a,8b-dihydrofuro-7-hydroxyfuro[3,2-b]-benzofuran-2(3H)-one (3). Preparation of [Cu((S,S)-2,6-bis(4-isopropyl-4,5-dihydrooxazol-2-yl)pyridine)](OTf) .

Copper(II) triflate (0.31 g), (S,S)-(iso-propyl)-pybox $\mathbf{4 b}(0.26 \mathrm{~g})$ and $4 \AA$ molecular sieves (ca 1 g) were dried under high vacuum for $45 \mathrm{~min}$. Dry distilled dichloromethane $(29 \mathrm{~mL})$ was added to the mixture of solids and the blue solution was stirred under nitrogen at room temperature for 4 h. 
Addition of 2-trimethylsilyloxyfuran 1 to 2-acetyl-1,4-benzoquinone 2 using [Cu((S,S)-2,6bis(4-isopropyl-4,5-dihydro-oxazol-2-yl)pyridine)](OTf) ${ }_{2}$ stoichiometrically. 2-Acetyl-1,4benzoquinone 2 ( $0.13 \mathrm{~g}, 0.88 \mathrm{mmol}$, prepared immediately before use) was added as a solid to the above blue solution of the copper(II) triflate complex and the resulting green mixture was cooled to $-100{ }^{\circ} \mathrm{C}$. After $15 \mathrm{~min} 2$-[(trimethylsilyloxy)]furan $\mathbf{1}(0.16 \mathrm{~mL})$ was added over $20 \mathrm{~min}$ via a septum and the mixture was allowed to come to room temperature then stirred overnight. The green mixture was transferred to a separating funnel containing aqueous $\mathrm{NaHCO}_{3}$ (5\%, 25 $\mathrm{mL})$ and extracted with dichloromethane $(3 \times 50 \mathrm{~mL})$. The combined dark reddish-brown extracts were washed with saturated aqueous $\mathrm{NaHCO}_{3}(25 \mathrm{~mL})$, saturated aqueous $\mathrm{NaCl}(25$ $\mathrm{mL}$ ), and dried $\left(\mathrm{Na}_{2} \mathrm{SO}_{4}\right)$. The organic phase was then filtered and the solvents were removed from the filtrate under reduced pressure. Purification of the residue by flash chromatography using hexanes-ethyl acetate (4:1) as eluent afforded the title adduct $3(0.13 \mathrm{~g}, 63 \%)$ as a yellow solid, m.p. $161-163{ }^{\circ} \mathrm{C}$ (lit. ${ }^{21}$ m.p. $164-5{ }^{\circ} \mathrm{C}$ ); $[\alpha]_{\mathrm{D}}{ }^{20}=-55.6^{\circ}$ (c = 0.97, $\mathrm{CDCl}_{3}$ ); (Found: $\mathrm{M}^{+}$, 234.05282, $\mathrm{C}_{2} \mathrm{H}_{10} \mathrm{O}_{5}$ requires 234.05276); $\delta_{\mathrm{H}}(400 \mathrm{MHz}), 2.80\left(3 \mathrm{H}, \mathrm{s}, \mathrm{CH}_{3}\right), 3.06-3.09(2 \mathrm{H}, \mathrm{m}$, H3), 5.36-5.44 (1H, td, $J$ 6.2, 6.2, $2.3 \mathrm{~Hz}, \mathrm{H3a}), 6.29(1 \mathrm{H}, \mathrm{d}, J 6.2 \mathrm{~Hz}, \mathrm{H} 8 \mathrm{~b}), 7.04$ (1H, d, $J 9.1$ Hz, H6), $7.08(1 \mathrm{H}, \mathrm{d}, J 9.1 \mathrm{~Hz}, \mathrm{H} 5), 12.5(1 \mathrm{H}, \mathrm{s}, \mathrm{OH}) ; \delta_{\mathrm{C}}(100 \mathrm{MHz}), 30.6\left(\mathrm{CH}_{3}\right), 35.4\left(\mathrm{CH}_{2}, \mathrm{C}-\right.$ 3), 80.7 (CH, C-3a), 84.3 (CH, C-8b), 116.3 (C, C-8a), 119.6 (C, C-5), 123.4 (CH, C-6), 125.6 (C, C-8), 153.9 (C, C-4a), 158.8 (C, C-7), 173.8 (C, C-2), 203.13 (C=O); m/z 234 (M+1, 83\%), 219 (M-CH $3,100 \%), 189$ (M-COOH, 28\%), 175 (219- $\left.\mathrm{CO}_{2}, 18 \%\right), 43\left(\mathrm{MeCO}^{+}, 28 \%\right)$.

(3aR*,8b $\left.R^{*}\right)-8$-Acetyl-3a,8b-dihydrofuro-2-oxofuro-[3,2-b]-benzofuran-(3H)-7-yl

(1'S,2'R,5'S)-menthyl carbonate. A sample of the above adduct 3 (0.048 g) in dichloromethane $(16 \mathrm{~mL})$ was treated with triethylamine $(108 \mu \mathrm{L})$, 4-dimethylaminopyridine $(0.011 \mathrm{~g})$ and $(+)$ menthyl chloroformate $(76 \mu \mathrm{L})$. The resultant yellow solution was stirred for $45 \mathrm{~min}$ at room temperature under nitrogen, during which time it changed colour to pale orange. The mixture was diluted with dichloromethane $(5 \mathrm{~mL})$ and the solution was washed with water $(5 \mathrm{~mL})$, aqueous $\mathrm{HCl}\left(5 \mathrm{~mL}, 1 \mathrm{~mol} \mathrm{~L}^{-1}\right)$ and aqueous $\mathrm{NaHCO}_{3}(5 \mathrm{~mL})$. The organic layer was dried $\left(\mathrm{Na}_{2} \mathrm{SO}_{4}\right)$ and concentrated under redued pressure. Purification of the residue by flash chromatography using hexanes-ethyl acetate $(6: 1)$ as the eluent afforded the menthyl carbonate derivatives (Found: 416.1836, $\mathrm{C}_{23} \mathrm{H}_{28} \mathrm{O}_{7}$ requires 416.1835). The enantiomeric excess of the initial adduct 3 was calculated by integration of the signals due to the $\mathrm{CH}_{3} \mathrm{CH}$ in the ${ }^{1} \mathrm{H}$ NMR spectrum, which established that the ratio of the two menthyl carbonate diastereoisomers was 2:1. $\delta_{\mathrm{H}}(400 \mathrm{MHz}$, $\left.\mathrm{CDCl}_{3}\right), 0.81\left[(0.66 \times 3) \mathrm{H}, \mathrm{d}, J 7.0 \mathrm{~Hz}, \mathrm{CHCH}_{3}\right], 0.83\left[(0.33 \times 3) \mathrm{H}, \mathrm{d}, J 7.0 \mathrm{~Hz}, \mathrm{CHCH}_{3}\right], 0.95(1 \mathrm{H}$, d, $J 6.8 \mathrm{~Hz}, \mathrm{CH}\left(\mathrm{CH}_{3}\right)_{2}, 2.61\left(1 \mathrm{H}, \mathrm{s}, \mathrm{COCH}_{3}\right), 2.98(1 \mathrm{H}, \mathrm{dd}, J 19.0,1.7 \mathrm{~Hz}, \mathrm{H} 3), 3.05(1 \mathrm{H}, \mathrm{dd}, J$ 19.0, $6.3 \mathrm{~Hz}, \mathrm{H3}), 4.58-4.66$ (1H, m, H-1'), 5.35-5.42 (1H, td, J 6.2, 6.2 and 1.6 Hz, H3a), 6.35 (1H, d, J $6.2 \mathrm{~Hz}, \mathrm{H} 8 \mathrm{~b}), 7.00(1 \mathrm{H}, \mathrm{d}, J 8.7 \mathrm{~Hz}, \mathrm{H} 6), 7.02(1 \mathrm{H}, \mathrm{d}, J 8.7 \mathrm{~Hz}, \mathrm{H} 5) ; \mathrm{m} / \mathrm{z} 416\left(\mathrm{M}^{+}\right.$,

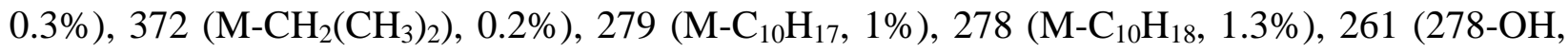
1.5\%), $234\left(\mathrm{C}_{11} \mathrm{H}_{18} \mathrm{O}_{5}, 93 \%\right), 219$ (234- $\left.\mathrm{CH}_{3}, 21 \%\right), 189$ (234- $\left.\mathrm{COOH}, 5 \%\right), 83\left(\mathrm{C}_{6} \mathrm{H}_{11}{ }^{+}, 100 \%\right)$.

\section{References}


1. Brimble, M. A. Pure Appl. Chem. 2000, 72, 1635.

2. Brimble, M. A.; Duncalf, L. J.; Nairn, M. R. Nat. Prod. Rev. 1999, 16, 267.

3. Brimble, M. A.; McEwan, J. F. Tetrahedron Asymmetry 1997, 8, 4069.

4. For reviews see: (a) Ghosh, A. K.; Mathivanan, P.; Cappiello, J. Tetrahedron Asymmetry, 1998, 9, 1. (b) Johnson, J. S.; Evans, D. A. Acc. Chem. Res. 2000, 33, 325.

5. Evans , D. A.; Kozlowski, M. C.; Murray, J. A.; Burgey, C. S.; Campos, K. R.; Connell, B. T.; Staples, R. J. J. Am. Chem. Soc. 1999, 121, 686.

6. Evans. D. A.; Cee, V. J.; Smith, T. E.; Fitch, D. M.; Cho, P. S. Angew. Chem. Int. Ed. 2000, 39, 2533.

7. Desimoni, G.; Faita, G.; Filiponne, S.; Mella, M.; Zampori, M. G.; Zema, M. Tetrahedron 2001, 57, 10203.

8. Giannis, A.; Sandhoff, K. Angew. Chem. Int. Ed. Engl. 1998, 28, 218.

9. Davies, I. W.; Gerena, l.; Lu, N.; Larsen, R. D.; Reider, P. J. J. Org. Chem. 1996, 61, 9629.

10. Nishiyama, H.; Kondo, M.; Nakamura, T.; Itoh, K. Organometallics 1991, 10, 500.

11. Evans, D. A.; Murry, J. A.; von Matt, P.; Norcross, R. D.; Miller, S. J. Angew. Chem. Int. Ed. Engl. 1995, 34, 798.

12. Brimble, M. A.; McEwan, J. F.; Turner, P. Tetrahedron Asymmetry 1997, 9, 1257.

13. Evans, D. A.; Barnes, D. M.; Johnson, J. S.; Leckta, T.; von Matt, P.; Mile, S. J.; Murry, A. A.; Norcross, R. D.; Shaunessy., E. A.; Campos, K. R. J. Am. Chem. Soc. 1999, 121, 7582.

14. Kloetzel, M. C.; Dayton, R. P.; Abadir, B. Y. J. Org. Chem. 1955, 20, 38.

15. McKennon, M. J.; Meyers, A. I.; Drauz, K.; Schwarm, M. J. Org. Chem. 1993, 58, 3568.

16. Newkome, G. R. J. Org. Chem. 1979, 44, 3816.

17. Biniecki, S. Acta Poloniae Pharmaceutica 1985, 42, 1.

18. Nespar, R.; Pregosin, P. S.; Puntener, K.; Worle, M. Helv. Chim. Acta 1993, 76, 2239.

19. Schaus, S. E.; Jacobsen, E. N. Organic Letters 2000, 2, 1001.

20. Totleben, M. J.; Prasad, J. S.; Simpson, J. H.; Chan, S. H.; Vanyo, D. J.; Kuehner, D. E.; Deshpande, R.; Kodersha, G. A. J. Org. Chem. 2001, 66, 1057.

21. Brimble, M. A.; Brimble, M. T.; Gibson, J. J. J. Chem. Soc., Perkin Trans. 1 1989, 179. 